\section{Pengaruh 5C Dan 7P Terhadap Pemberian Kredit}

Studi Kasus Pada PT. Bank Negara Indonesia, Tbk Cabang Bogor dan

PT. Bank Rakyat Indonesia, Tbk Cabang Bogor

\author{
Theresia Sasmita dan Ratih Puspitasari \\ Program Studi Manajemen, Institut Bisnis dan Informatika Kesatuan \\ Bogor, Indonesia \\ E - Mail : theresia.sasmita@ibik.ac.id
}

Determinants of Government Bank Lending

\title{
ABSTRACT
}

BNI and BRI is a bank financial institutions that has a role in providing credit to the public, especially those in areas that have not been reached by other commercial banks. The purpose of this study was to determine the effect of $5 C$ and $7 P$ simultaneously and partially on the provision of credit at PT. Bank Negara Indonesia (BNI) Bogor, Tbk and PT. Bank Rakyat Indonesia (BRI), Tbk Bogor. The population of this research is all non-performing credit customers at PT. Bank Negara Indonesia (BNI) Tbk and Bank Rakyat Indonesia (BRI) Tbk Bogor in 2018. The data were analyzed using multiple regression analysis. The results of this study indicate that $5 C$ and $7 P$ have a positive and significant effect on credit purchasing decisions in both banks.

Keywords: 5C, 7P, loan, bank

\begin{abstract}
ABSTRAK
PT. Bank Tabungan Negara (BTN), Tbk dan PT. Bank Negara Indonesia (BRI), Tbk merupakan lembaga keuangan bank yang memiliki peranan dalam pemberian kedit kepada masyarakat terutama yang berada di daerah yang belum terjangkau oleh bank umum lainnya. Tujuan penelitian ini adalah untuk mengetahui pengaruh $5 \mathrm{C}$ dan $7 \mathrm{P}$ secara simultan dan parsial terhadap pemberian kredit pada PT. Bank Negara Indonesia (BNI) Cabang Bogor, Tbk dan PT. Bank Rakyat Indonesia (BRI), Tbk Cabang Bogor. Populasi penelitian ini adalah seluruh nasabah kredit bermasalah di PT. Bank Negera Indonesia (BNI) Tbkdan Bank Rakyat Indonesia (BRI) Tbk Cabang Bogor tahun 2018. Data dianalisis menggunakan analisis regresi berganda. Hasil penelitian ini menunjukkan bahwa $5 \mathrm{C}$ dan $7 \mathrm{P}$ berpengaruh positif dan signifikan terhadap keputusan pembelian kredit di kedua bank.
\end{abstract}

Kata Kunci: 5C, 7P, kredit, bank

\section{PENDAHULUAN}

Pertumbuhan yang cepat dari perbankan, menuntut dunia perbankan pun turut berkembang dan menuntut persaingan yang ketat antara sesama bank.Semua berusaha untuk mendapatkan banyak nasabah dan memperoleh keuntungan setinggi mungkin.

Di negara berkembang, perbankan terutama di bidang perkreditan, memiliki peranan yang sangat dominan dan penting. Perkreditan selalu dibutuhkan bagi pengembangan usaha, yaitu oleh pengusaha yang tengah mengembangkan usaha maupun pengusaha yang baru akan memulai usaha. Dapat dikatakan bahwa kredit memegang peran yang sangat penting bagi suksesnya pembangunan.

Dalam hal kegiatan bank memberikan fasilitas kredit, merupakan pendapatan terbesar dan resiko kerugian sebagian besar bersumber pada kegiatan tersebut, sehingga bila tidak dikelola dengan baik dan disertai pengawasan yang memadai akan mengancam kelangsungan hidup bank tersebut. Hal tersebut mengindikasikan bahwa pendapatan

JABKES

Jurnal Aplikasi Bisnis

Kesatuan

Vol. 1 No. 1,2021
page. $1-10$

page. $1-10$
IBI Kesatuan

ISSN $x x x x-x x x x$

DOI: $10.37641 /$ jabkes.v1i1.562 
Determinants of Government Bank Lending

\section{2}

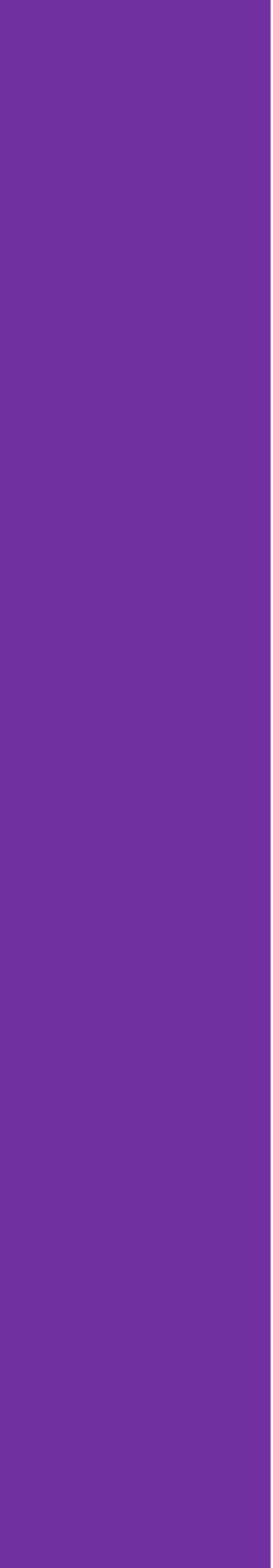

utama perbankan didapat melalui selisih bunga pinjaman dan bunga simpanan.Hal ini juga menjadi alasan mengapa kredit sangat penting bagi sebuah bank. Kualitas kredit yang baik akan sangat membantu bank dalam upaya menigkatkan keuntungan.

PT. Bank Tabungan Negara (BTN), Tbk dan PT. Bank Negara Indonesia (BRI), Tbk merupakan lembaga keuangan bank yang memiliki peranan dalam pemberian kedit kepada masyarakat terutama yang berada di daerah yang belum terjangkau oleh bank umum lainnya. Produk kredit yang ditawarkan oleh PT. Bank Negara Indonesia (BNI), Tbk dan PT. Bank Negara Indonesia (BRI), Tbk yaitu kredit umum. Kedua Bank milik pemerintah tersebut memandang bahwa resiko kredit yang timbul dalam pemberian kredit masih sangat dominan karena kegiatan bank paling banyak masih di sektor kredit, maka dari itu resiko kredit yang mengancam bank harus di antisipasi secara tepat.

Hal ini tentu saja akan mengakibatkan kerugian bagi bank. Oleh karena itu manajer bank harus mengadakan seleksi terhadap permohonan kredit.Hal-hal tersebut dapat dihindari sistem informasi akuntansi yang memadai dalam pemberian kredit diharapkan dapat menjamin bahwa dalam pelaksanaan pemberian kredit dapat terkendali dan mampu mencegah terjadinya kesalahan yang dapat merugikan bank dan dapat mencegah terjadinya pemberian kredit yang tidak sehat.

Dalam praktik perbankan, kredit macet merupakan sesuatu yang tidak dapat dihindari.Hal yang bisa dilakukan oleh pihak bank adalah meminimalisir kemungkinan terjadinya kredit macet.Ada beberapa faktor yang menyebabkan kredit macet.Timbulnya kredit-kredit macet, selain karena adanya indikasi debitur yang tidak mau membayar kewajibannya, juga terlihat dari prosedur pemberian kredit yang mengalami penyimpangan atau tidak layak. Kasus kredit macet dapat disebabkan oleh beberapa faktor ekstern dan intern Bank.

Kredit bermasalah bank secara umum disebabkan oleh dua faktor, yaitu faktor internal dan faktor eksternal (Ismail, 2010).Kredit bermasalah dari faktor internal bank diantaranya analisis yang kurang tepat, adanya kolusi antara pejabat bank yang menangani kredit dan nasabah, keterbatasan pengetahuan pejabat bank terhadap jenis usaha debitur, campur tangan terlalu besar dari pihak terkait, kelemahan dalam melalukan pembinaan dan monitoring kredit debitur, dan sebagainya.

Sedangkan kredit bermasalah dari faktor eksternal terdiri dari unsur kesengajaan yang dilakukan oleh nasabah dan unsur ketidaksengajaan.Contoh unsur kesengajaan yaitu :nasabah sengaja tidak melakukan pembayaran angsuran kepada bank, debitur melakukan ekspansi terlalu besar, penggunaan dana yang tidak sesuai dengan tujuan, dan lain sebaginya. Sedangkan unsur ketidaksengajaan dari faktor eksternal kredit bermasalah seperti usaha debitur yang terbatas, usaha debitur tidak dapat bersaing dengan pasar, perubahan kebijakan pemerintah, serta bencana alam, dan sebagainya.

Permasalahan yang biasanya timbul dapat terjadi pada saat pertama kali diberikannya kucuran dana oleh bank kepada pihak debitur, seperti pemberian kredit yang dilakukan tanpa akad perjanjian kredit yang tentunya hal ini sungguh merupakan kejadian yang sangat tidak masuk akal dan jelas akan sangat merugikan pihak debitur, atau bisa juga kredit itu bermasalah di tengah masa perkreditan. Kredit yang bermasalah di tengah masa perkreditan misalnya seperti seorang debitur yang mengalami kesulitan keuangannya sehingga pembayaran kewajiban atas kredit tidak dapat dilakukan sesuai dengan ketentuan yang telah disepakati bersama sebelumnya.

Kemudian bisa juga diakibatkan oleh kondisi di luar bisnis debitur, seperti kondisi keamanan yang tidak mendukung untuk berjalannya proses bisnis debitur tersebut atau juga kondisi alam yang tidak bersahabat seperti terjadinya bencana alam, cuaca yang buruk dan lain-lain yang tentunya semua kondisi tersebut akan sangat menghambat berjalannya proses bisnis debitur dan tentunya akan berdampak secara langsung kepada bank sebagai debitur dengan tidak dapat dipenuhinya kewajiban debitur kepada kreditur.

Analisis 5C dan 7P serta analisis kelayakan merupakan analisis yang dipakai oleh lembaga keuangan/bank dalam mengantisipasi terhadap kredit macet termasuk bagi Bank BNI, Tbk dan Bank BRI, Tbk.Analisis 5C dan 7P memiliki persamaan, yaitu apaapa yang terkandung dalam $5 \mathrm{C}$ dirinci lebih lanjut dalam prinsip $7 \mathrm{P}$ di samping lebih 
terinci juga jangkauan analisisnya lebih luas dari 5C. Prinsip analisis kredit dengan 5C itu sendiri terdiri dari :Character, capaciity, capital, collateral, dan condition. Sedangkan prinsip analisis menggunakan 7P ialah: Personality, Party, Purpose, Prospect, Payment, Protability, dan Protection.

Analisis tersebut berlaku untuk semua Bank, baik bank konvensional, bank syariah ataupun lembaga keuangan lainnya.Hanya saja pada bank syariah berlaku tambahan 1S, menjadi 5C + 1S + 7P, dimana 1S adalah Analisis Syariah.Penilaian ini dilakukan untuk menegaskan bahwa usaha yang akan dibiayai benar-benar usaha yang tidak melanggar syariah sesuai dengan fatwa DSN. "Pengelola tidak boleh menyalahi hukum syariah Islam dalam tindakannya yang berhubungan dengan mudharabah

Tidak menutup kemungkinan, meminimalisir kredit bermasalah dalam kenyatan bisnis perbankan sehari-hari, tidak dapat dihindari secara mutlak, namun setiap bank harus tetap berusaha untuk mencegah terulangnya kasus itu.Setiap karyawan bank yang jabatannya berkaitan dengan kegiatan perkreditan harus menyadari besarnya tanggung jawab untuk menekan sekecil mungkin risiko munculnya kasus kredit bermasalah.Masalah tersebut dapat berupa angka kredit macet (non performing loan) yang tinggi.

Tabel 1. Data Angka Kredit Macet Gross Bank BNI, Tbk dan Bank BRI, Tbk

\begin{tabular}{|cc|c|c|}
\hline \multicolumn{3}{|c|}{ BNI } & \multicolumn{3}{|c|}{ BRI } \\
Semester 1 2018 & Semester 1 2019 & Semester 1 2018 & Semester 1 2019 \\
\hline $1,81 \%$ & $2,1 \%$ & $2,31 \%$ & $2,39 \%$ \\
\hline
\end{tabular}

Sumber: http://Keuangan.kontan.co.id

Berdasarkan data atas baik Bank BNI, Tbk dan Bank BRI, Tbk, mengalami peningkatan angka kredit macet (NPL) yang berfariasi.Bank BNI, Tbk, mencatat data angka kredit macet (NPL) periode perbandingan tahun 2018 sampai dengan tahun 2019 semester 1 mengalami peningkatan sebesar 0,92\%. Selanjutnya pada Bank BRI, Tbk mencatat, pada periode perbandingan tahun 2018 sampai dengan 2019 semester 1 mengalami peningkatan angka kredit macet (NPL) sebesar 0,08\%.

Tujuan dari diadakan penelitian ini adalah untuk memperoleh informasi yang diperlukan guna mengetahui pengaruh $5 \mathrm{C}$ dan $7 \mathrm{P}$ terhadap pemberian kredit pada PT. Bank Negara Indonesia (BNI), TbkCabang Bogor dan PT. Bank Rakyat Indonesia (BRI), Tbk Cabang Bogor.

\section{METODE PENELITIAN}

Metode penelitian ini adalah metode penelitian kuantitatif, yaitu metode penelitian yang berlandaskan pada filsafat potivisme, digunakan untuk meneliti pada populasi atau sampel tertentu, Sugiyono $(2018 ; 8)$. Karena penelitian ini berupa angka-angka dan analisis menggunakan statistik untuk mengukur serta mendapatkan hasil penelitian melului kuesioner.

Pendekatan penelitian yang digunakan adalah dengan pendekatan deskriptif dan survey, yaitu suatu metode penelitan yang mengambil sampel dari suatu populasi dan menggunakan kuesioner sebagai alat pengumpulan data (Riduwan, 2006).

Jenis Data yang digunakan dalam penelitian ini adalah:

1) Data kuantitatif, yaitu data numerik yang dapat memberikan penafsiran yang kokoh atau dengan kata lain data ini berupa kredit yang disalurkan, jumlah kredit bermasalah, data nasabah kredit bermasalah, dan tingkat NPL pada Bank Negera Indonesia (BNI) Tbk Cabang Bogor dan Bank Rakyat Indonesia (BRI) Tbk Cabang Bogor.

2) Data kualitatif, yaitu analisis yang dilakukan terhadap data-data yang non-angka seperti hasil wawancara dan bacaan dari buku-buku yang terkait dengan penelitian(Sugiyono, 2015:23).

Populasi yang menjadi objek penelitian merupakan seluruh nasabah kredit bermasalah di PT. Bank Negera Indonesia (BNI) Tbk dan Bank Rakyat Indonesia (BRI) Tbk Cabang Bogor tahun 2018. Pengambilan sampel berdasarkan populasi yang mudah

Determinants of Government Bank Lending

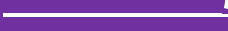


Determinants of

Government Bank Lending

$\underline{4}$ diakses untuk memperoleh informasi, dengan mengambil sampel nasabah yang berada di daerah penelitian yang mempunyai pinjaman/kredit bermasalah periode tahun 2018 .

Tabel 3. Pembagian Sampel

\begin{tabular}{|cc|c|} 
No & \multicolumn{1}{c}{ Nama bank } & $\begin{array}{c}\text { Jumlah Nasabah yang kolektibilitas } \\
\text { kredit kurang lancar }\end{array}$ \\
\hline 1 & Bank BNI Tbk, Cabang Bogor & 25 \\
\hline 2 & Bank BRI Tbk, Cabang Bogor & 30 \\
\hline
\end{tabular}

Untuk mengukur kualitas data, dilakukan uji validitas, uji reliabilias dan uji asumsi klasik. Lalu Data dianalisis menggunakan analisis regresi berganda.

Kerangka Pemikiran Konseptual

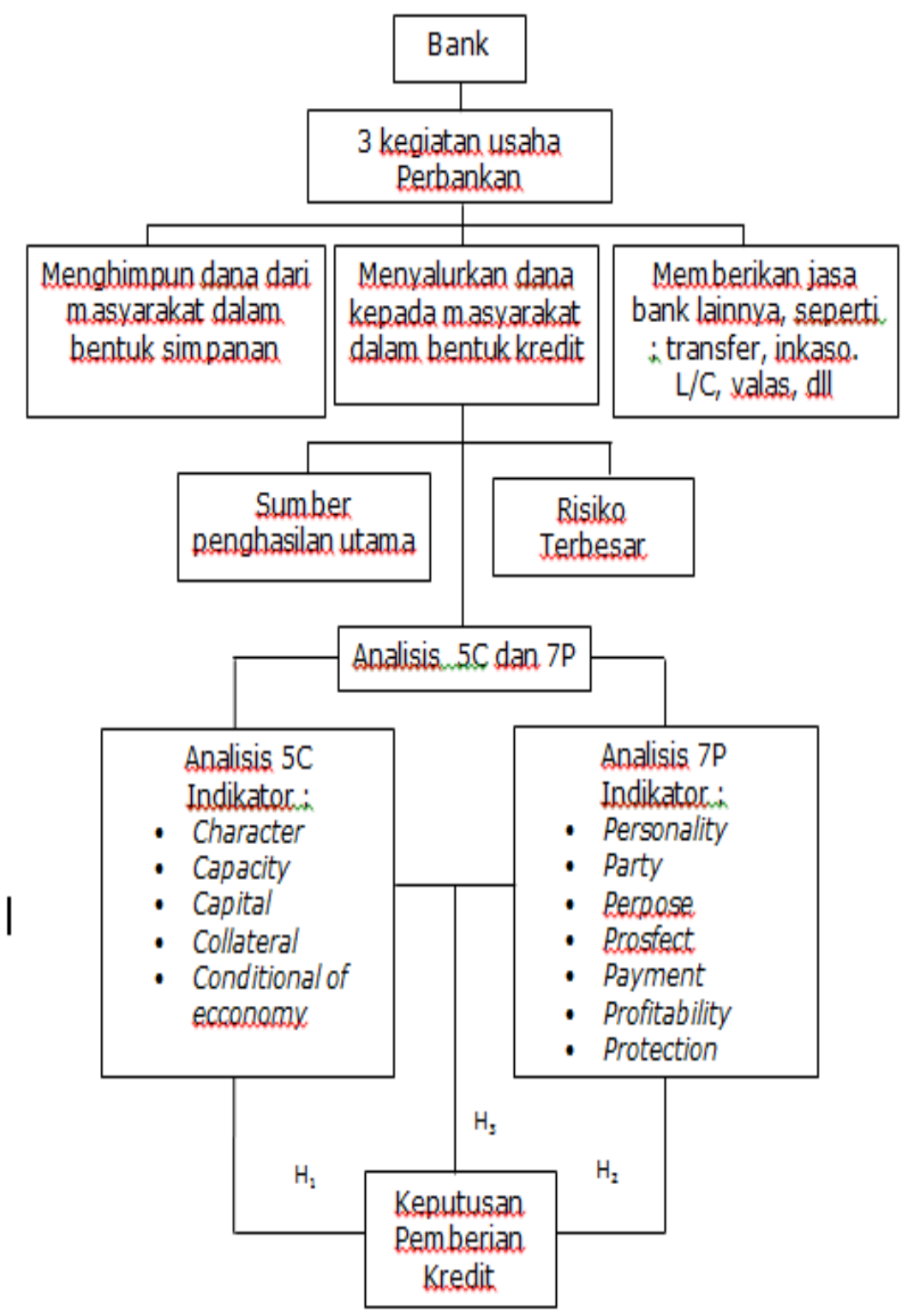

Gambar 1. Kerangka Penelitian

HASIL DAN PEMBAHASAN

Identitas Responden

Dalam Tabel 4 dijelaskan bahwa umur responden dari Nasabah Bank BNI, Tbk Cabang Bogor yang mengalami kesukaran pembayaran kredit terbesaryaitu dengan umur $31-50$ tahun $(48 \%)$, dan yang terkecil dengan umur $>50$ tahun berjumlah 4 orang $(16 \%)$. 
Sedangkan data umur responden dari Nasabah Bank BRI, Tbk Cabang Bogor yang mengalami kesukaran pembayaran kredit terbesar yaitu dengan umur 31-50 tahun sebanyak 15 orang $(50 \%)$, dan yang terkecil dengan umur $>50$ tahun berjumlah 7 orang $(23 \%)$.

Tabe1 4. Distribusi Frekuensi Responden Berdasarkan Umur

\begin{tabular}{|c|c|c|c|c|}
\hline \multirow{2}{*}{ Karakteristik } & \multicolumn{2}{|c|}{ BNI } & \multicolumn{2}{|c|}{ BRI } \\
\hline & Frekuensi (f) & Persentase $(\%)$ & Frekuensi (f) & Persentase $(\%)$ \\
\hline \multicolumn{5}{|l|}{ USIA } \\
\hline$<=30$ tahun & 9 & 36 & 8 & 27 \\
\hline 31-50 tahun & 12 & 48 & 15 & 50 \\
\hline$>50$ tahun & 4 & 16 & 7 & 23 \\
\hline Total & 25 & 100 & 30 & 100 \\
\hline \multicolumn{5}{|l|}{ GENDER } \\
\hline Laki-laki & 18 & 72 & 21 & 70 \\
\hline Perempuan & 7 & 28 & 9 & 30 \\
\hline Total & 25 & 100 & 30 & 100 \\
\hline \multicolumn{5}{|c|}{ TINGKAT PENDIDIKAN } \\
\hline SMA/sederajat & 10 & 40 & 8 & 27 \\
\hline DI/DII/DIII & 10 & 40 & 6 & 20 \\
\hline SI & 5 & 20 & 13 & 43 \\
\hline S2/S3 & - & - & 3 & 10 \\
\hline Total & 25 & 100 & 30 & 100 \\
\hline \multicolumn{5}{|l|}{ JENIS USAHA } \\
\hline Perusah. Dagang & 9 & 36 & 6 & 20 \\
\hline Perusahaan Jasa & 4 & 16 & 7 & 23 \\
\hline Wirausaha & 8 & 32 & 10 & 34 \\
\hline Lain-lain & 4 & 16 & 7 & 23 \\
\hline Total & 25 & 100 & 30 & 100 \\
\hline \multicolumn{5}{|l|}{ PENGALAMAN } \\
\hline $1-5$ tahun & 6 & 24 & 5 & 17 \\
\hline 6-10 tahun & 13 & 52 & 21 & 70 \\
\hline$>10$ tahun & 6 & 24 & 4 & 13 \\
\hline Total & 25 & 100 & 30 & 100 \\
\hline
\end{tabular}

Sumber: Data yang diolah 2020

Tabel 4 menjelaskan bahwa responden dari Nasabah Bank BNI, Tbk Cabang Bogor yang mengalami kesukaran pembayaran kredit terbesar adalah terbanyak adalah yang beridentitas kelamin laki-laki, responden dengan tingkat pendidikan SMA/Sederajat dan pendidikan DI/DII/DIII dengan jumlah masing-masing 10 orang responden (40\%) dan yang terkecil yaitu dengan pendidikan terakhir SI dengan jumlah 5 orang (20\%), responden berjenis usaha perusahaan dagang dengan jumlah 9 responden $(36 \%)$ dan yang terkecil yaitu jenis usaha perusahaan jasa dan lain-lain dengan jumlah masing-masing 4 orang (16\%), responden dengan pengalaman 6-10 tahun berjumlah 13 responden (52\%) dan yang terkecil yaitu dengan pengalaman 1-5 tahun dan $>10$ tahun dengan jumlah masing-masing 6 orang (24\%),

Responden Nasabah Bank BRI, Tbk Cabang Bogor yang mengalami kesukaran pembayaran kredit terbesar yaitu dengan umur 31-50 tahun sebanyak 15 orang (50\%), beridentitas laki-laki berjumlah 21 orang $(70 \%)$, dan identitas perempuan berjumlah 9 orang $(28 \%)$, responden dengan tingkat pendidikan terakhir SI dengan jumlah13orang responden (43\%) dan yang terkecil yaitu dengan pendidikan terakhir S2/S3 dengan jumlah 3 orang $(10 \%)$, responden dengan jenis usaha wirausaha berjumlah 10 responden (34\%) dan yang terkecil yaitu jenis usaha perusahaan dagang dengan jumlah 6 orang (20\%), serta berdasarkan pengalaman terbanyak adalah berpengalaman 6-10 tahun

Determinants of Government Bank Lending 
Determinants of Government Bank Lending

\section{6}

6

berjumlah 21 responden $(70 \%)$ dan yang terkecil yaitu dengan pengalaman $>10$ tahun dengan jumlah 4 orang (13\%).

\section{Uji Kualitas Data}

Uji Validitas pada penelitian ini diawali dengan menentukan $r$ tabel maka dilakukan dengan cara yaitu ditetapkannya jumlah sampel sebanyak 55 orang, Konstruk $=3$, maka didapat nilai df-nya $=55-3=22$. Pada tabel nilai Koefesien Korelasi " $r$ " dengan nilai df $=52$, maka nilai $\mathrm{r}$ tabel $=0,2681$. Hasil uji validitas di kedua bank, terlihat semua

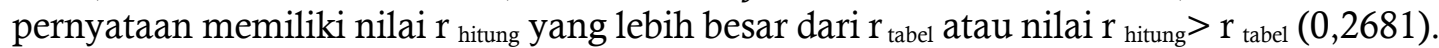

Uji reliabilitas dilakukan dengan melihat nilai cronbach's alpha $>0,60$, dan berdasarkan uji tersebut dapat disimpulkan bahwa variabel 5C, 7P dan pemberian kredit pada Bank BNI, Tbk, Cabang Bogor dinyatakan "reliabel", dikarenakan memiliki nilai crombach's alpha lebih besar dari 0,6. $(0,744>0,6)$. Demikian pula untuk data variabel $5 \mathrm{C}, 7 \mathrm{P}$ dan pemberian kredit pada Bank BRI, Tbk, Cabang Bogor dinyatakan "reliabel", dikarenakan memiliki nilai crombach's alpha lebih besar dari 0,6 $(0,673>0,6)$.

\section{Analisis Regresi Linear Berganda}

Analisis kuantitatif dengan regresi berganda untuk mengetahui besarnya pengaruh secara kuantitatif dari suatu perubahan kejadian (variabel $\mathrm{X}$ ) terhadap kejadian lainnya (variabel $\mathrm{Y}$ ). atau pengaruh $5 \mathrm{C}$ dan $7 \mathrm{P}$ terhadap pemberian kredit.

Tabel 5 Hasil Analisis Regresi Berganda Variabel Independen terhadap Variabel Dependen Responden Bank BNI

\begin{tabular}{|lr|c|c|}
\hline \multicolumn{1}{c}{ Keterangan } & Koefisien & $t_{\text {hitung }}$ & Signifikansi \\
\hline (Konstanta) & 8.830 & 2.597 & 0.016 \\
\hline $5 \mathrm{C}$ & 0.361 & 4.680 & 0.004 \\
\hline $7 \mathrm{P}$ & 0.833 & 6.781 & 0.000 \\
\hline $\mathrm{R}$ & 0.831 & & \\
\hline $\mathrm{R}$ Square & 0.690 & & \\
\hline Adjusted R Square & 0.662 & & \\
\hline $\mathrm{F}_{\text {hitung }}$ & 24.499 & & 0.000 \\
\hline
\end{tabular}

Dependent Variable: Pemberian Kredit

Sumber: Data Primer Diolah

Berdasarkan tabel 5 dapat disimpulkan bahwa :

1. Rumus Regresi Linear Berganda dari Variabel 5C , 7P dan variabel pemberian kredit dalah sebagai berikut: $\quad \mathrm{Y}=\mathrm{a}+\mathrm{bx}_{1}+\mathrm{bx}_{2}$ menjadi $\mathrm{Y}=8,830+0,361 \mathrm{x}_{1}+0,833 \mathrm{x}_{2}$

2. Pengaruh variabel $5 \mathrm{C}$ terhadap variabel pemberian kredit diwakili dengan nilai sebesar 0,361 yang berarti bahwa jika terjadi kenaikan 1 satuan nilai 5Cmaka akan menaikan nilai pemberian kredit sebesar 0,361 satuan.

3. Pengaruh variabel $7 \mathrm{P}$ terhadap variabel pemberian kredit diwakili dengan nilai sebesar 0,833 yang berarti bahwa jika terjadi peningkatan 1 satuan nilai $7 \mathrm{P}$ maka akan menaikan nilai pemberian kredit sebesar 0,833 satuan.

4. Jika tidak terjadi peningkatan atau penurunan dari nilai variabel $5 \mathrm{C}$ dan $7 \mathrm{P}$ maka nilai variabel pemberian kredit sebesar 8,830 satuan.

5. Diperoleh nilai AdjustedR Square $=0,662$ atau $66,2 \%$, dapat dinyatakan bahwa variabel 5C dan variabel 7P mampu menjelaskan keragaman dari variabel pemberian kredit adalah sebesar $66,2 \%$, sedangkan sisanya sebesar $33,8 \%$ dipengaruhi oleh variabel yang lain yang tidak diteliti pada penelitian ini.

6. Diperoleh nilai f-hitung sebesar 24,499 Dikarenakan nilai $f_{\text {hitung }}(24,499)>$ nilai $f_{\text {tabel }}$ $(3,17)$, serta nilai Sig. 0,000 , maka dapat disimpulkan terdapat pengaruh yang positif dan signifikan antara variabel5C dan variabel $7 \mathrm{P}$ secara simultan dengan variable pemberian kredit pada Bank BNI, Tbk Cabang Bogor.

7. Diperoleh nilai $t_{\text {hitung }}$ untuk masing-masing variabel yaitu : variabel $5 \mathrm{C}(4,680)$, dan variabel $7 \mathrm{P}(6,781)$. Nilai $t_{\text {hitung }}$ untuk variabel $5 \mathrm{C}$ sebesar $4,680>$ nilai $t_{\text {tabel }}(0,679)$. Maka tolak Ho artinya terdapat pengaruh yang positif dan signifikan antara variabel 5C dengan pemberian kredit pada Bank BNI, Tbk Cabang Bogor. Nilai $t_{\text {hitung }}$ untuk 
variabel $7 \mathrm{P}$ sebesar $6,781>$ nilai $\mathrm{t}_{\text {tabel }}(0,679)$. Maka tolak Ho artinya terdapat pengaruh yangpositif dan signifikan antara variabel $7 \mathrm{P}$ dengan variabel pemberian kredit pada Bank BNI, Tbk Cabang Bogor.

Tabel 6 Hasil Analisis Regresi Berganda Variabel Independen terhadap Variabel Dependen Responden Bank BRI

\begin{tabular}{|c|c|c|c|}
\hline Keterangan & Koefisien & $t_{\text {hitung }}$ & Signifikansi \\
\hline (Konstanta) & 28.633 & 7.215 & 0.000 \\
\hline $5 \mathrm{C}$ & 0.382 & 4.936 & 0.008 \\
\hline $7 \mathrm{P}$ & 0.341 & 3.332 & 0.042 \\
\hline $\mathrm{R}$ & 0.816 & & \\
\hline R Square & 0.666 & & \\
\hline Adjusted R Square & 0.643 & & \\
\hline $\mathrm{F}_{\text {hitung }}$ & 12.537 & & 0.021 \\
\hline
\end{tabular}

Dependent Variable: Pemberian Kredit

Sumber: Data Primer Diolah

Berdasarkan tabel di atas dapat disimpulkan bahwa :

1. Rumus Regresi Linear Berganda dari Variabel 5C , 7P dan variabel pemberian kredit dalah sebagai berikut: $\mathrm{Y}=\mathrm{a}+\mathrm{bx}_{1}+\mathrm{bx}_{2}$ menjadi $\mathrm{Y}=28,633+0,382 \mathrm{x}_{1}+0,341 \mathrm{x}_{2}$

2. Pengaruh variabel $5 \mathrm{C}$ terhadap variabel pemberian kredit diwakili dengan nilai sebesar 0,382 yang berarti bahwa jika terjadi kenaikan 1 satuan nilai $5 \mathrm{C}$ maka akan menaikan nilai pemberian kredit sebesar 0,382 satuan.

3. Pengaruh variabel $7 \mathrm{P}$ terhadap variabel pemberian kredit diwakili dengan nilai sebesar 0,341 yang berarti bahwa jika terjadi peningkatan 1 satuan nilai 7P maka akan menaikan nilai pemberian kredit sebesar 0,341 satuan.

4. Jika tidak terjadi peningkatan atau penurunan dari nilai variabel $5 \mathrm{C}$ dan $7 \mathrm{P}$ maka nilai variabel pemberian kredit sebesar 28,633 satuan.

5. Diperoleh nilai Adjusted $R$ Square $=0,643$, dapat dinyatakan bahwa variabel $5 \mathrm{C}$ dan variabel 7P mampu menjelaskan keragaman variabel pemberian kredit sebesar 64,3\%, sedangkan sisanya sebesar $35,7 \%$ dipengaruhi oleh variabel yang lain yang tidak diteliti pada penelitian ini.

6. Diperoleh nilai f-hitung sebesar 12,537 Dikarenakan nilai $f_{\text {hitung }}(12,537)>$ nilai $f_{\text {tabel }}$ $(3,17)$, serta nilai Sig. 0,021 , maka dapat disimpulkan terdapat pengaruh yang positif dan signifikan antara variabel $5 \mathrm{C}$ dan variabel $7 \mathrm{P}$ secara simultan dengan variabelpemberian kredit pada Bank BRI, Tbk Cabang Bogor.

a. Diperoleh nilai $t_{\text {hitung }}$ dari masing-masing variabel yaitu : variabel $5 \mathrm{C}(4,935)$ nilai sig 0,008 , dan variabel $7 \mathrm{P}(3,332)$ dan nilai sig 0,42 . Nilai thitung untuk variabel $5 \mathrm{C}$ sebesar4,935 $>$ nilai $t_{\text {tabel }}(0,679)$. Maka tolak Ho artinya terdapat pengaruh yang positif dan signifikan antara variabel $5 \mathrm{C}$ dengan pemberian kredit pada Bank BRI, Tbk Cabang Bogor. Nilai thitung untuk variabel $7 \mathrm{P}$ sebesar 3,332> nilai tabel $(0,679)$. Maka tolak Ho artinya terdapat pengaruh yangpositif dan signifikan antara variabel $7 \mathrm{P}$ dengan variabel pemberian kreditpada Bank BRI, Tbk Cabang Bogor.

\section{Pembahasan}

Berdasarkan hasil dari Uji Koefesien Determinasi yang dilakukan oleh penulis, dapat disimpulkan bahwapengaruh variabel5C dan variabel $7 \mathrm{P}$ terhadap variabelpemberian kredit pada Bank BNI, Tbk Cabang Bogor sebesar 66,2\%, selanjutnya pengaruh variabel5C dan variabel $7 \mathrm{P}$ terhadap variabelpemberian kredit pada Bank BRI, Tbk Cabang Bogor sebesar 64,3\%. Hal ini sesuai dengan hasil penelitian oleh Ismiyati (2016) dengan tujuan untuk menguji dan menganalisis pengaruh character, capacity, capital, collateral dan condition of economic terhadap kualitas kredit pada BPR di Kabupaten Magelang yang menunjukkan : sebagai bukti empiris untuk BPR di Kabupaten Magelang bahwa prinsip 5C kredit masih relevan untuk diperhatikan dan dikencangkan agar kualitas kredit bisa meningkat.
Determinants of Government Bank Lending 
Determinants of Government Bank Lending

8

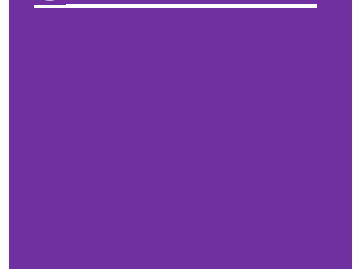

Selanjutnya dari hasil Uji F yang dilakukan penulis maka dapat disimpulkan terdapat pengaruh yang positif dan signifikan antara variabel $5 \mathrm{C}$ dan variabel $7 \mathrm{P}$ secara simultan dengan variabel pemberian kredit pada Bank BNI, Tbk Cabang Bogor dan Bank BRI, Tbk Cabang Bogor. Hal tersebut sesuai dengan penelitian yang dilakukan oleh Komang Wulan Lestari,Gusti Purnawati, dan Kadek Sinarwati (2015), yang menyimpulkan bahwa terdapat pengaruh secara simultan variabel $5 \mathrm{C}$ terhadap pemberian kredit pada PT. Bank Pembangunan Daerah BaliCabang Singaraja

Berdasarkan hasil penelitian yang dilakukan penulis untuk menentukan apakah terdapat pengaruh secara parsial antara variabel 5C dan 7P terhadap pemberian kredit baik pada Bank BNI, Tbk Cabang Bogor dan Bank BRI, TbkCabang Bogor, dapat disimpulkan bahwa terdapat pengaruh positif dan signifikanantara variabel $5 \mathrm{C}$ dan $7 \mathrm{P}$ terhadap variabel pemberian kredit secara parsial.

\section{PENUTUP}

Berdasarkan hasil penelitian yang dilakukan penulis mengenai Pengaruh 5C (Character, capacity, capital, collateral, conditional of economy) dan 7P (Personality, party, perpose, prosfect, payment profitability, protection) terhadap pemberian kredit pada Bank BNI, Tbk Cabang Bogor dan Bank BRI, Tbk Cabang Bogor, maka dapat disimpulkan sebagai berikut :

a. Variabel 5C (Character, capacity, capital, collateral, conditional of economy) berpengaruh positif terhadap variabel pemberian kredit pada PT. Bank Negara Indonesia (BNI), Tbk Cabang Bogor.

b. Variabel 5C (Character, capacity, capital, collateral, conditional of economy) berpengaruh positif terhadap variabel pemberian kredit pada dan PT. Bank Rakyat Indonesia (BRI), Tbk Cabang Bogor.

c. Variabel 7P (Personality, party, perpose, prosfect, payment profitability, protection) bepengaruh positif terhadap variabel pemberian kredit pada PT. Bank Negara Indonesia (BNI), Tbk Cabang Bogor.

d. Variabel 7P (Personality, party, perpose, prosfect, payment profitability, protection) berpengaruh positif terhadap variabel pemberian kredit pada PT. Bank Rakyat Indonesia (BRI), Tbk Cabang Bogor.

e. Variabel 5C (Character, capacity, capital, collateral, conditional of economy) dan variabel 7P (Personality, party, perpose, prosfect, payment profitability, protection) berpengaruh positif secara simultan terhadap variabel pemberian kredit pada PT. Bank Negara Indonesia (BNI), Tbk Cabang Bogor.

f. Variabel 5C (Character, capacity, capital, collateral, conditional of economy) dan variabel 7P (Personality, party, perpose, prosfect, payment profitability, protection) berpengaruh positif secara simultan terhadap variabel pemberian kredit pada PT. Bank Rakyat Indonesia (BRI), Tbk Cabang Bogor.

g. Besarnya pengaruh variabel 5C (Character, capacity, capital, collateral, conditional of economy) dan variabel 7P (Personality, party, perpose, prosfect, payment profitability, protection) terhadap variabel pemberian kredit pada Bank BNI, Tbk Cabang Bogor sebesar $66,2 \%$.

h. Besarnya pengaruh variabel 5C (Character, capacity, capital, collateral, conditional of economy) dan variabel 7P (Personality, party, perpose, prosfect, payment profitability, protection) terhadap variabel pemberian kredit pada Bank BRI, Tbk Cabang Bogor sebesar $64,3 \%$.

\section{DAFTAR PUSTAKA}

[1] Abdullah, Thamrin. 2012. Bank dan Lembaga Keuangan. Jakarta: PT. Raja Grafindo Persada.

[2] Adkon, Riduwan. (2006). Metode dan Teknik Menyusun Tesis. Bandung: Alfabeta.

[3] Ahmad Dunia, Firdaus dan Wasilah.2011.Akuntansi Biaya. Edisi Dua. Jakarta : Salemba Empat 
[4] Ajmi, D.N. and Iriyadi, I., 2018. Analisis Penentuan Tarif Rawat Inap dan Perhitungan Harga Pokok Pada Klinik Utama Rawat Inap dr.

[5] Akbar, B., Aziz, H.A., Djazuli, A., Kowi, M. and Amyar, F., 2018, February. Performance Effectiveness Measurement of Village Funding Management Using Fuzzy Inference System (FIS) Method. In Conference Proceedings Jakarta Indonesia, ICABE 2018.

[6] Andrayani, I.P. and Nurendah, Y., 2013. Prosedur Penjualan Sepeda Motor Pada Dealer Honda Pt. Sanprima Sentosa Bogor (Doctoral dissertation, Institut Bisnis dan Informatika Kesatuan).

[7] Apriansyah, A., Pramiudi, U. and Setiawan, H., 2019. Analisis Komparatif Perlakuan Akuntansi Atas Pendapatan Dan Beban. Jurnal Ilmiah Akuntansi Kesatuan, 7(1), pp.197-204.

[8] Arthesa, Ade dan Edia Handiman. 2006. Bank \& Lembaga Keuangan Bukan Bank, PT Indeks. Jakarta.

[9] Beatrice, C. and Fahmi, A., 2019. Analisis Pengaruh Harga Pokok Produksi Terhadap Penentuan Harga Jual Produk Pada Perusahaan. Jurnal SearchGate. Sekolah Tinggi Ilmu Ekonomi Kesatuan. Jakarta.

[10] Fahmi, Irham.2011. Analisa Laporan Keuangan, Bandung. Alphabeta.

[11] Hadiwijaya, Rivai. Wirasasmita.2000. Analisis Kredit. Bandung: CV. Pioner Jaya.

[12] Humaeni, A., Muanas, M. and Sudradjat, S., 2019. Peranan Program Yongjin Erp Sebagai Sistem Informasi Akuntansi Pengendalian Persediaan Bahan Baku. Jurnal Ilmiah Akuntansi Kesatuan, 7(1), pp.213-218.

[13] Ismail. 2010. Manajemen Perbankan : Dari Teori Menuju Aplikasi. Jakarta: Kencana.

[14] Kasmir. 2010. Manajemen Perbankan. Jakarta: PT Grafindo Persada.

[15] ------. 2013. Dasar-Dasar Perbankan. Jakarta: PT Raja Grafindo Persada

[16] Kiryanto, Ryan. 2007. LangkahTerobosan Mendorong Ekspansi Kredit. Economic Review No. 208. Juni 2007

[17] Kuncoro, Mudrajad dan Suhardjono. 2002. Manajemen Perbankan:Teori dan Aplikasi. Yogyakarta: BPFE.

[18] Muanas, M. and Mulia, I., 2020. Peningkatan Pemahaman Pembukuan Koperasi Melalui Pemograman Sederhana. Jurnal Abdimas Dedikasi Kesatuan, 1(2), pp.160170.

[19] Mulianita, A., Sutarti, S. and Triandi, T., 2019. Pengaruh Dewan Komisaris Dan Komite Audit Terhadap Kinerja Keuangan Perbankan Syariah Yang Terdaftar Di Bank Indonesia. Jurnal Ilmiah Akuntansi Kesatuan, 7(1), pp.219-223.

[20] Muljono, Teguh Pujo. 1999. AnalisaLaporan Keuangan Untuk Perbankan. Jakarta: Djambatan.

[21] Mulyana, M., 2012. Consumer Behaviour: Sukses Dengan Memahami Konsumen.

[22] Munawir. 2010. Analisis Laporan Keuangan. Yogyakarta.Liberty Yogyakarta.

[23] Nurachmad, E. and Sukamto, A., 2020. Pelatihan Persiapan Studi Lanjut Di Jurusan Teknologi Informasi. Jurnal Abdimas, 4(1), pp.61-70.

[24] Pamungkas, B., Avrian, C. and Ibtida, R., 2019. Factors influencing audit findings of the Indonesian district governments' financial statements. Cogent Business \& Management, 6(1), p.1673102.

[25] Papalangi, Riska. 2013. Penerapan SPI Dalam Menunjang Efektivitas Pemberian Kredit UKM Pada PT. BRI (Persero) Tbk Manado. Jurnal EMBA 1213 Vol.1

[26] Santoso, Singgih. 2010.Statistik Nonparametrik Konsep dan Aplikasi dengan SPSS. Jakarta: PT. Elex Media Komputindo.

[27] Siamat, Dahlan. 2001. Manajemen Lembaga Keuangan. Jakarta: Lembaga Penerbit Fakultas Ekonomi Universitas Indonesia.

[28] Sinungan, Muchdarsyah. (2003). Produktivitas apa dan Bagaimana. Jakarta: Bumi Aksara

[29] Siregar, Sofyan . 2010. Metode Penelitian Kuantitatif. Jakarta. 


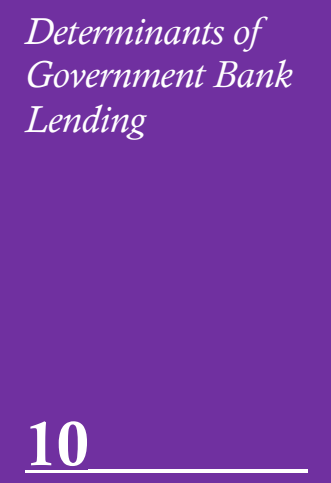

Determinants of Government Bank Lending

\section{0}

[30] Sugiyono. 2008. Metode Penelitian Bisnis (Pendekatan Kuantitatif, Kualitatif dan R\&D). Cetakan kelima belas. Bandung: Alfabeta.

[31] Sugiyono, 2009, Metode Penelitian Kuantitatif, Kualitatif dan R\&D, Bandung : Alfabeta

[32] Sugiyono. 2018. Metode Penelitian Kuantitatif, Kualitatif, dan R\&D. Bandung: Alfabeta

[33] Supriyono,Maryanto. 2011. Buku Pintar Perbankan. Yogjakarta: Andi Kasmir. 2000. Manajemen Perbankan. Jakarta: PT. Raja GrafindoPersada

[34] Suriya. 2012. Pengaruh Faktor Internal Bank dan Internal Debitur terhadap Kredit Bermasalah Pada PT Bank Negara Indonesia (Persero), Tbk. Makassar: Program S1 Fakultas Ekonomi dan Bisnis Universitas Hasanuddin.

[35] UU No. 10 Tahun 1998 Tentang Perbankan

[36] Undang-Undang Republik Indonesia No. 23 Tahun 1999 Tentang Bank Indonesia

[37] Yudha, A., Marlina, T. and Fahmi, A., 2017. Pelatihan Membuat Laporan Keuangan dengan Microsoft Excel BUMDes Pagelaran. Jurnal Abdimas, 1(1), pp.912.

[38] Yudhistira, L.D., Mulyana, M. and Mashadi, M., 2013. TINJAUAN PELAYANAN PRIMA PADA TOYOTA SETIAJAYA DALAM MENARIK KONSUMEN. Jurnal Online Mahasiswa-Manajemen, 1(1). 